\title{
'Mostly Good and Always Modern'? The Limits of the Modern for Women in the Home Magazine in the 1920s
}

Lucinda Janson

The Australian National University

Abstract: This article explores the complex and contradictory attitudes towards modernity in Sydney Ure Smith's high-end Australian women's magazine, the Home. The magazine was published in the cosmopolitan environment of $1920 \mathrm{~s}$ Sydney, in a period in which Australia was both exhilarated and alarmed by the power of the modern. Ure Smith's Home both reflected and challenged this Australian modernity. While a number of scholars have maintained that the Home was a significant purveyor of modern art and design, this article argues that the magazine was often ambivalent about, and hostile to, artistic and literary modernism, as well as cultural and social modernity more broadly. It frequently represented these female-dominated movements as trivial or even degenerate. The Home shared many of its writers with conservative, masculinist publications such as the Bulletin, and reproduced much of their chauvinistic humour. While the magazine championed some women's attempts to seek careers beyond the domestic sphere, the Home nevertheless clearly delineated the boundaries of women's potential freedom. A focus on the magazine's textual, as well as its visual, content exposes the limits of the Home's construction of its own contemporaneity.

Australia in the 1920s was gripped by the power of the modern, which simultaneously exhilarated and alarmed the nation. Sydney Ure Smith's high-end women's magazine the Home reflected these complex and contradictory reactions to modernity. Instead of taking Ure Smith at his word when he wrote that the Home sought to promote a style and taste that would be 'mostly good and always modern', this article seeks 
to interrogate and challenge the unthinking equation of the Home with modernity. ${ }^{1}$ The magazine's conservatism is embedded in its very title, which presupposes that women's primary interest is in the 'home'.

During the 1920s Australia experienced both the emergence of technological modernity, and the rise of modernist movements in art and literature. Modernity describes a historical period characterised by increasing social, cultural and material changes brought about by mechanisation and by developments in mass communication technologies. ${ }^{2}$ Marshall Berman has argued that the upheavals of modernity began at the end of the eighteenth century, and were characterised by advances in industrial, scientific and communication technologies, the growth of urbanisation, the dominance of nation-states, and a rapidly expanding and globalising market. ${ }^{3}$ By the early twentieth century, these developments contributed to the perception that the world was becoming 'new' and more modern. ${ }^{4}$ This sense of modern life as transitory, frenetic and disruptive of tradition was reflected in literary and artistic modernism, which was characterised by a disjointed and self-reflexive style. ${ }^{5}$ Modernist art and literature rebelled against the strict realism of nineteenth-century modes in favour of a more experimental and ambiguous expression. While the largest centres of modernist art and literature were in northern hemisphere metropoles such as London, Paris and New York, there was nevertheless considerable modernist activity in Australia during the interwar period. It was largely women who were promulgators of literary and artistic modernism in Australia. They range from Eleanor Dark and Marjorie Barnard's use of modernistic literary techniques to the more overt artistic modernism of Grace Cossington Smith, Margaret Preston, Thea Proctor, Clarice Beckett, Grace Crowley, Dorrit Black and Anne Dangar. ${ }^{6}$

1 Sydney Ure Smith, 'The Home: How It Proposes To Be of Service to You', Home, February 1920, 3.

2 Rita Felski, The Gender of Modernity (Cambridge, MA: Harvard University Press, 1995), 12-13; Marshall Berman, All That Is Solid Melts into Air: The Experience of Modernity (London: Verso, 1983), 16. 3 Berman, All That Is Solid Melts into Air, 17-19.

4 Berman, All That Is Solid Melts into Air, 17-18; Jill Julius Matthews, Dance Hall \& Picture Palace: Sydney's Romance with Modernity (Sydney: Currency Press, 2005), 14-16.

5 Felski, The Gender of Modernity, 13; Tim Armstrong, Modernism: A Cultural History (Cambridge: Polity Press, 2005), 4-5.

6 Susan Carson, 'A Girl's Guide to Modernism's Grammar: Language Politics in Experimental Women's Fiction', Hecate 30, no. 1 (2004): 176-83; Julian Croft, 'Responses to Modernism, 1915-1965', in The Penguin New Literary History of Australia, ed. Laurie Hergenhan et al. (Melbourne: Penguin, 1988), 409-29; Lesley Harding and Sue Cramer, Cubism \& Australian Art (Melbourne: The Miegunyah Press, 2009); Deborah Hart, Grace Cossington Smith (Canberra: National Gallery of Australia, 2005); Rosalind Hollinrake, Clarice Beckett: Politically Incorrect (Melbourne: The Ian Potter Museum of Art, The University of Melbourne, 1999). 
Scholars such as Rita Felski have drawn attention to the links between the modern and the feminine, and have argued that the conditions of modernity allowed women to achieve visibility and prominence in contemporary life. ${ }^{7}$ The social upheavals of modernity made it increasingly possible for women to find lives outside the domestic sphere, as new technologies allowed many women to find employment in factories and offices. ${ }^{8}$ Women also emerged as significant consumers and creators of the new 'mass' culture, including fashion, design, advertising, architecture, photography, radio and cinema. ${ }^{9}$ Yet, this feminisation of various aspects of culture provoked male anxieties about the 'corruption' of art. ${ }^{10} \mathrm{~A}$ divide emerged between 'high' and 'mass' culture, with the latter seen as inferior due to its feminine associations. ${ }^{11}$ Some men also became alarmed at women's increasing visibility in public life and in the workplace. ${ }^{12}$

Critical discourse around the participation of Australia in these modern developments during the interwar period has shifted over time, and has influenced interpretations of the Home. During the 1970s and 1980s, scholarship on Australian cultural life in the interwar period elided women's contributions and presented Australia as parochial and anti-modern. Geoffrey Serle argued that Australian taste in the arts during this period was 'conservative and backward', while in his 1981 book Inventing Australia, Richard White claimed that Australia only began to develop cultural 'maturity' in the late 1930s. ${ }^{13}$ Such a male-dominated approach to the cultural and artistic life of the period provoked a reconsideration by feminist scholars, who drew attention to Australian women's considerable and early contributions to modernist art and design. Janine Burke, Mary Eagle and Helen Topliss all published books during the 1980s and 1990s creating a female genealogy of modernist art in Australia, beginning with Norah Simpson's introduction of post-impressionism to Australia in

\section{Felski, Gender of Modernity, 18-19.}

8 Felski, Gender of Modernity, 18-19.

9 Miriam Bratu Hansen, 'The Mass Production of the Senses: Classical Cinema as Vernacular Modernism', Modernism/Modernity 6, no. 2 (1999): 60, doi.org/10.1353/mod.1999.0018.

10 Laurie Duggan, Ghost Nation: Imagined Space and Australian Visual Culture, 1901-1939 (Brisbane: University of Queensland Press, 2001), 78-83.

11 Andreas Huyssen, After the Great Divide: Modernism, Mass Culture, Postmodernism (Bloomington, IN: Indiana University Press, 1986), 47-50.

12 Charles Fox and Marilyn Lake, 'The Sexual Division of Labour', in Australians at Work: Commentaries and Sources, ed. Charles Fox and Marilyn Lake (Melbourne: McPhee Gribble, 1990), $144-45$.

13 Geoffrey Serle, From Deserts the Prophets Come: The Creative Spirit in Australia 1788-1972 (Melbourne: Heinemann, 1973), 91; Richard White, Inventing Australia: Images and Identity, 16881980 (Sydney: Allen \& Unwin, 1981), 137-44. 
1913. ${ }^{14}$ They cited the Home as a significant purveyor and champion of women's art in discussions of the modern and modernist work of Thea Proctor, Grace Cossington Smith, Margaret Preston, Grace Crowley and Dorrit Black. While it is true that many of these artists were featured in the Home, revisionist scholars' attempts to include women in Australian cultural history overstated the Home's approval of modern art. Such an uncritical appraisal of the Home's modernity is evident throughout the literature, from Caroline Jordan and Angela Woollacott's argument that the Home disseminated modernist women's art, to Mary Mackay and Robert Holden's discussions of the Home's depiction of the modern leisured woman on its covers, and John Docker's claim that the Home promoted Australian and European artistic modernity and advanced a 'pro-feminist' agenda. ${ }^{15}$ Even the recent collaborative work on the Home by Victoria Kuttainen, Susann Liebich and Sarah Galletly has maintained that the magazine portrayed itself as 'modern and sophisticated' and that it advocated a cosmopolitan, internationally orientated modernity. ${ }^{16}$

14 Janine Burke, Australian Women Artists, 1840-1940 (Melbourne: Greenhouse Publications, 1980); Mary Eagle, Australian Modern Painting Between the Wars, 1914-1939 (Sydney: Bay Books, 1989); Helen Topliss, Modernism and Feminism: Australian Women Artists, 1900-1940 (Sydney: Craftsman House, 1996). Humphrey McQueen and others drew attention to the work of Margaret Preston during the late 1970s and early 1980s in Humphrey McQueen, The Black Swan of Trespass: The Emergence of Modernist Painting in Australia to 1944 (Sydney: Alternative Publishing Cooperative, 1979) and Ian North, Humphrey McQueen and Isobel Seivl, The Art of Margaret Preston (Adelaide: Art Gallery Board of South Australia, 1980), but she was the only female artist of the period accorded this treatment until the feminist reconsiderations of the 1980s.

15 Caroline Jordan, 'Designing Women: Modernism and its Representation in Art in Australia', in Strange Women: Essays in Art and Gender, ed. Jeanette Hoorn (Melbourne: Melbourne University Press, 1994), 29; Angela Woollacott, To Try Her Fortune in London: Australian Women, Colonialism, and Modernity (Oxford: Oxford University Press, 2001), 209; Mary Mackay, 'Almost Dancing: Thea Proctor and the Modern Woman', in Wallflowers and Witches: Women and Culture in Australia 1910-1945, ed. Maryanne Dever (Brisbane: University of Queensland Press, 1994), 26-37; Robert Holden, Cover Up: The Art of Magazine Covers in Australia (Sydney: Hodder \& Stoughton, 1995), 24-27, 97-99; John Docker, 'Feminism, Modernism, and Orientalism in the Home in the 1920s', in Journalism: Print, Politics and Popular Culture, ed. Ann Curthoys and Julianne Schultz (Brisbane: University of Queensland Press, 1999), 117-30.

16 Victoria Kuttainen and Susann Liebich, 'Worldly Tastes: Mobility and the Geographical Imaginaries of Interwar Australian Magazines', Transfers 7, no. 1 (2017): 52-69, doi.org/10.3167/ TRANS.2017.070105; Victoria Kuttainen, 'Illustrating Mobility: Networks of Visual Print Culture and the Periodical Contexts of Modern Australian Writing', Journal of the Association for the Study of Australian Literature 17, no. 2 (2018): 1-16; Victoria Kuttainen, Susann Liebich and Sarah Galletly, The Transported Imagination: Australian Interwar Magazines and the Geographical Imaginaries of Colonial Modernity (Amherst, New York: Cambria Press, 2018), 5. 
While such interpretations of the Home's modernity are understandable in light of the critical neglect of women's role in the cultural life of the interwar period, scholars nevertheless have misstated the extent of the Home's commitment to modernity and women's place within it. It is certainly important to stress the role that women artists, writers, designers and critics played in developing, and advocating for, an Australian modernism. Yet it is also crucial not to celebrate uncritically all such contributions as unambiguously 'modern' and 'modernist'. Instead, it is important to interrogate the Home's modernity, and to draw attention to the limitations of its claims to being 'wholly modern'. David Carter has highlighted the false dichotomy that critics have established between Sydney Ure Smith's high-art magazine, Art in Australia, which was supposedly anti-modernist, and the Home's championing of modern art and life. ${ }^{17}$ Carter claims that the Home was less interested in advocating for modernity than critics have argued, yet he does not substantiate this assertion with examples from the Home. This article builds on Carter's observation, and contends that a focus on the magazine's textual, as well as its visual, content exposes the limits of the Home's construction of its own contemporaneity.

In this article, I analyse the Home's interplay of text and image, and challenge the critical consensus that the magazine promoted a feminine modernity and modernism. I argue that the magazine was often ambivalent about, and even hostile to, artistic and literary modernism, and cultural modernity. It frequently represented these movements, which were largely female-dominated, as trivial or even degenerate. I demonstrate that the Home shared many of its writers with conservative, masculinist publications such as the Bulletin, and reproduced much of their chauvinistic humour. The Home placed severe limitations on women's engagement with modernity, and its audience was confined to wealthy, leisured, urban women. While the magazine championed some women's attempts to seek careers beyond the domestic sphere, the Home nevertheless clearly delineated the boundaries of women's potential freedom.

17 David Carter, Always Almost Modern: Australian Print Cultures and Modernity (Melbourne: Australian Scholarly Publishing, 2013), 51-52. 
Drawing on the theory of periodical studies, I consider the content of the magazine within its social and cultural contexts. ${ }^{18}$ Following Sean Latham and Robert Scholes, I examine the Home as 'an autonomous print object', rather than as a collection of discrete articles and images. ${ }^{19} \mathrm{I}$ take into account what Carter has described as the 'institutional aspects' of magazines and their culture, including the Home's audience, the context of its publication and dissemination, and the role it played within a wider field of Australian interwar periodicals. ${ }^{20}$ Carter draws attention to the key role that periodicals played during the 1920s in mediating for local readers the social and cultural transformations of modernity. ${ }^{21}$

It is also important to stress the magazine's fraught relationship with the middlebrow. While the terms 'highbrow' and 'lowbrow' had been in existence since the late nineteenth century, the idea of the 'middlebrow' emerged in the 1920s, prompted by new, often feminised, forms of mass communication technologies, including radio, popular fiction and women's magazines. ${ }^{22}$ Like its relationship to modernity itself, the Home displayed an uneasy relationship to the term 'middlebrow'. The Home positioned itself as a 'superior publication' and included discussion of 'high' modernist art and literature. At the same time, however, the magazine also published middlebrow realist fiction and focused on women's 'decorative' art. Carter argues that the concept of the middlebrow was positioned relationally in opposition to 'high' modernism on one hand and mass commercial culture on the other hand. ${ }^{23}$ For all its intellectual and artistic pretensions, the Home often finds itself in just such a middle space. Such a meeting of high and popular culture, of consumerism and art, is evident throughout the Home and colours its attitudes towards modernity. Hence, the Home's relationship to the middlebrow both reflects and shapes its ambivalent relationship to modernity and women's place within it.

18 Adrian Bingham, 'The Digitization of Newspaper Archives: Opportunities and Challenges for Historians', Twentieth Century British History 21, no. 2 (2010): 230, doi.org/10.1093/tcbh/hwq007. 19 Sean Latham and Robert Scholes, 'The Rise of Periodical Studies', Publications of the Modern Language Association 121, no. 2 (2006): 529, doi.org/10.1632/003081206X129693.

20 David Carter, 'Magazine Culture: Notes Towards a History of Australian Periodical Publication 1920-1970', in Australian Literature and the Public Sphere, ed. Alison Bartlett, Robert Dixon, and Christopher Lee (Toowoomba: Association for the Study of Australian Literature, 1999), 69.

21 David Carter, 'The Conditions of Fame: Literary Celebrity in Australia between the Wars', Journal of Modern Literature 39, no. 1 (2015): 171, doi.org/10.2979/jmodelite.39.1.170.

22 Carter, Always Almost Modern, 131-33.

23 Carter, Always Almost Modern, 130. 
While the Home magazine was in print from 1920 to 1942, this article focuses on the magazine during the 1920s. ${ }^{24}$ During this decade Thea Proctor produced her famous cover illustrations, and the magazine published a wide range of literary and artistic work. The Home was printed on heavy art paper, with its cover and many pages of advertisements in colour, and it made lavish use of photography. ${ }^{25}$ Its standards of production were higher even than American Vogue in 1921. ${ }^{26}$ Moreover, the Home cultivated an elite audience, with its circulation never exceeding 7,000 copies per edition. By way of contrast, the Australian Woman's Mirror, launched in 1924 as a weekly publication by the Bulletin, boasted that it sold 126,000 copies every week. ${ }^{27}$ The Woman's Mirror, consisting of 64 pages without gloss or colour, was aimed at a mass audience of Australian women, primarily housewives who would have appreciated the paper's recipes, household hints and dress patterns. ${ }^{28}$

The Home's many advertisements for products such as motor vehicles, Parisian fashions and luxury cruises were designed to appeal to leisured, upper-middle-class women who had the money and time to enjoy art, fashion and travel. This wealthy audience would have recognised themselves in the magazine's cover art, most notably in Thea Proctor's modern designs that depicted independent women driving, travelling, shopping and dancing. ${ }^{29}$ A number of critics, such as Mary Mackay, Robert Holden, Pamela Niehoff and Catriona Moore, have described the women on Proctor's covers as 'flappers'. ${ }^{30}$ While it is certainly true that Proctor depicted women wearing contemporary fashions and undertaking

24 Gavin Souter, Company of Heralds: A Century and a Half of Australian Publishing by John Fairfax Limited and Its Predecessors, 1831-1981 (Melbourne: Melbourne University Press, 1981), 155-56; Frank S. Greenop, History of Magazine Publishing in Australia (Sydney: The K. G. Murray Publishing Co., 1947), 244.

25 Greenop, History of Magazine Publishing in Australia, 242.

26 Nancy D. H. Underhill, Making Australian Art 1916-49: Sydney Ure Smith, Patron and Publisher (Oxford: Oxford University Press, 1991), 198.

27 Australian Woman's Mirror, 24 April 1928, cover.

28 Vane Lindesay, The Way We Were: Australian Popular Magazines, 1856-1969 (Melbourne: Oxford University Press, 1983), 103-05.

29 Sarah Engledow, 'The World of Thea Proctor', in The World of Thea Proctor, Barry Humphries, Andrew Sayers, and Sarah Engledow (Melbourne: Craftsman House, 2005), 41.

30 Mackay, 'Almost Dancing', 28; Holden, Cover Up, 96; Pamela Niehoff, 'The New Woman and the Politics of Identity', in Strange Women: Essays in Art and Gender, ed. Jeanette Hoorn (Melbourne: Melbourne University Press, 1994), 40; Catriona Moore, 'Modern Women: Full Throttle', in Sydney Moderns: Art for a New World, ed. Deborah Edwards and Denise Mimmocchi (Sydney: Art Gallery of New South Wales, 2013), 86. 
modern leisure pursuits, these women cannot be considered flappers. The flapper of the period was generally an adolescent girl or young woman, not the more mature women depicted on Proctor's covers.

Flappers were largely working-class young women who had abandoned domestic service because of its lack of freedom, and instead worked in the new clerical occupations or in shops or factories. ${ }^{31}$ This modern girl became increasingly visible on city streets during the $1920 \mathrm{~s} .{ }^{32}$ While she was associated with modern consumer and leisure cultures, she would have been more likely to watch popular films and to 'jazz' in the new, improvised style of dance than to attend exhibitions of modernist art and design. ${ }^{33}$ While both flappers and the upper-middle-class readers of the Home sought out the latest fashions, their budgets would have been wildly different. The Home's fashion pages were filled with clothes from Paris and London, which would have been unattainable luxuries for the workingclass flapper. Jill Matthews characterises the Home's Sydney audience as 'the upper echelons of [the city's] society', comprising approximately 10 per cent of the population. ${ }^{34}$ The Home was careful to differentiate itself and its audience from the flapper. Thus, an article about 'How the Movies Influence Fashion' condescendingly described the 'flapper' as a girl whom the movies taught to 'build up her hair in the Pickford manner'. ${ }^{35}$ The satirical tone of this piece distinguished the lower-class flapper from the affluent and always fashionable reader of the Home.

31 Barbara Cameron, 'The Flappers and the Feminists: A Study of Women's Emancipation in the 1920s', in Worth Her Salt: Women at Work in Australia, ed. Margaret Bevege, Margaret James and Carmel Shute (Sydney: Hale \& Iremonger, 1982), 259.

32 Liz Conor, The Spectacular Modern Woman: Feminine Visibility in the 1920s (Bloomington, IN: Indiana University Press, 2004), 209-10.

33 On the use of the word 'jazz' to mean both the musical style and a form of dance see Katharine Brisbane, ed., Entertaining Australia: An Illustrated History (Sydney: Currency Press, 1991), 181. While Bruce Johnson, The Inaudible Music: Jazz, Gender and Australian Modernity (Sydney: Currency Press, 2000), has argued that jazz music exhibited some of the formal properties of 'high' modernist music of the period, such as dissonance, weakening of tonality and musical coloration, jazz was nevertheless largely considered to be a popular form of musical expression.

34 Matthews, Dance Hall \& Picture Palace, 36.

35 'How the Movies Influence Fashion', Home, February 1920, 18. This refers to Mary Pickford, a Canadian-born American silent movie star who, at the height of her popularity during the 1920s, was a major influence on women's fashions, and most notably on their hair. See Cristel Schmidt, 'Crown of Glory: The Rise and Fall of the Mary Pickford Curls', in Mary Pickford: Queen of the Movies, ed. Cristel Schmidt (Lexington: University Press of Kentucky, 2012), 169-84. 
The Home's modernity was reserved for a certain upper-middle-class urban woman, who had the leisure to travel, dress fashionably and expensively, and to devote herself to the latest literary and artistic culture. The ambiguities of this affluent modernity are evident in Proctor's August 1925 cover, which depicted a modern woman driving a car alongside her Victorian counterpart in a horse-drawn carriage (see Figure 1). ${ }^{36}$ The cover contrasted the life of the emancipated modern woman and the restricted world of the nineteenth-century woman. The modern woman is wearing fashionable 'boyish' clothes, and stands confidently with a cigarette insouciantly raised. By way of contrast, the Victorian woman's plumed bonnet, parasol and impractical skirts make her appear modest and retiring. The vignette in the background highlights the technological progress of the 1920s, as cars became an increasingly common form of transport. ${ }^{37}$ For the Home's well-to-do female audience, driving one's own car represented the emancipatory power of modern technology to liberate women from the constraints of the Victorian era. ${ }^{38}$ Yet, while car prices dropped rapidly during this period, owning a vehicle remained impossible for most Australians. ${ }^{39}$ The cover thus depicted a modernity that would have been available to only a limited group. Moreover, Proctor's image does not straightforwardly depict the triumph of the modern woman over her old-fashioned counterpart, as some critics have suggested. ${ }^{40}$ The visual prominence of the nineteenth-century woman demonstrates Proctor's fascination with the Victorian past. ${ }^{41}$ This double vision is replicated in the pages of the Home, which was just as interested in looking back to the past as it was in advocating for the modern. The same edition of the Home included a spread of 'Belles of Yesteryear', alongside fashion plates depicting the modern woman. ${ }^{42}$ Hence, the Home was not simply interested in championing modernity, and the modern woman, at the expense of the past.

\footnotetext{
36 Thea Proctor, cover design, Home, August 1925. See Figure 1.

37 'Australia's Motor Vehicle Fleet since the 1920s', Year Book Australia 2001, Australian Bureau of Statistics, 25 January 2001, www.abs.gov.au/ausstats/abs@.nsf/0/39F42D529B84BEA2CA2569D E0028B410?Open, accessed 28 May 2020.

38 Georgine Clarsen, Eat My Dust: Early Women Motorists (Baltimore, MD: The Johns Hopkins University Press, 2008), 106-07.

39 Frank Bongiorno, 'Search for a Solution, 1923-39', in The Cambridge History of Australia: Volume 2: The Commonwealth of Australia, ed. Alison Bashford and Stuart Macintyre (Cambridge: Cambridge University Press, 2013), 68, doi.org/10.1017/CHO9781107445758.034.

40 Mackay, 'Almost Dancing', 33-34.

41 Engledow, 'The World of Thea Proctor', 43.

42 'Belles of Yesteryear', Home, August 1925, 56D.
} 
ANU Historical Journal II, Number 2

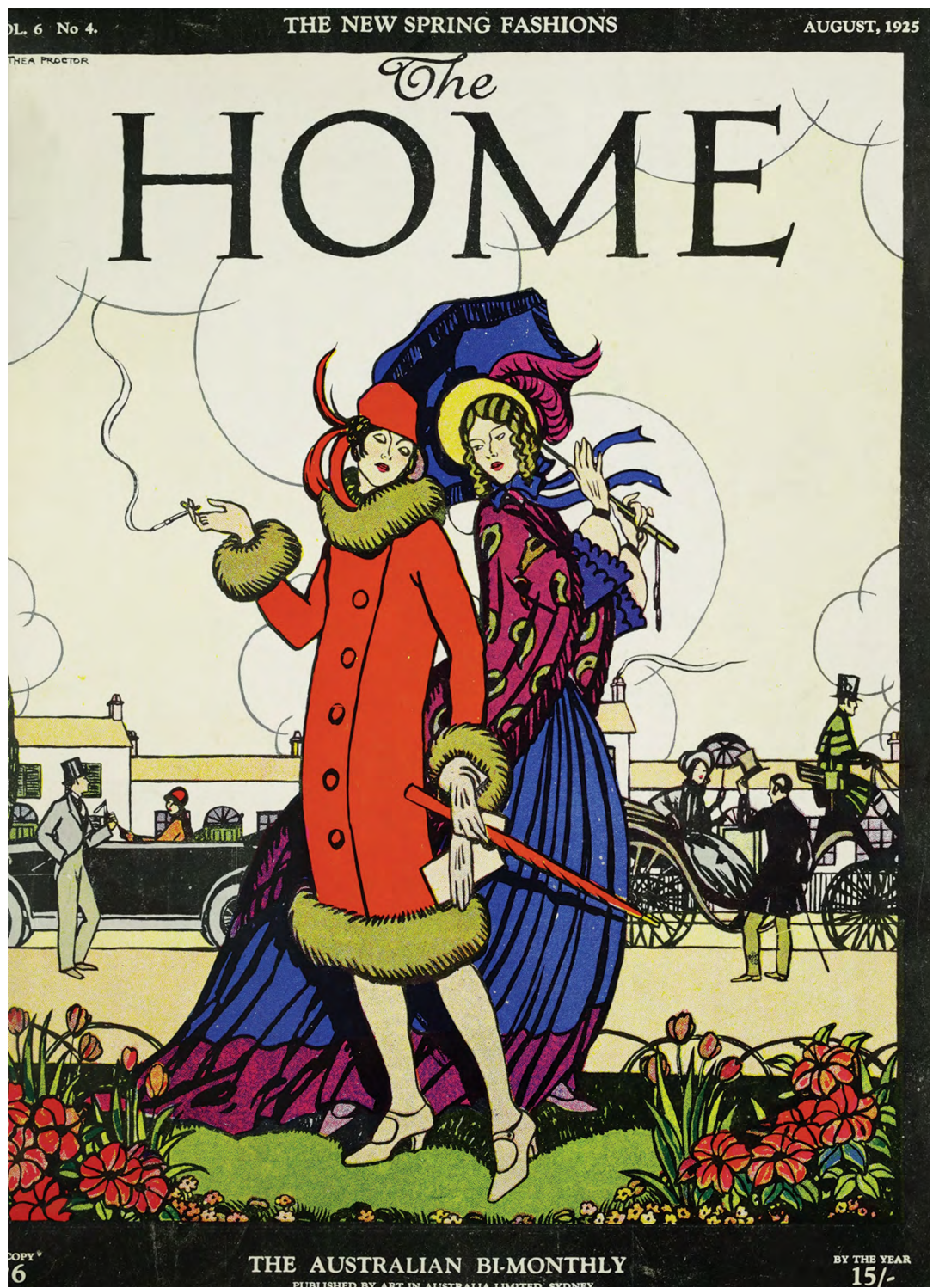

Figure 1: Thea Proctor, Cover Design, Home, August 1925. 
If Thea Proctor depicted the stylish modern woman admiringly, even with reservations, other Home covers more openly satirised contemporary women's attempts to enjoy life outside the domestic sphere. Thus, the cover of the March 1927 edition featured a caricature by Victoria (Vic) Cowdroy of a society woman going hunting (see Figure 2). ${ }^{43}$ Cowdroy was known for her satirical cartoons, which appeared in Aussie, the Bulletin and $M a n \cdot{ }^{44}$ Here she depicts the modern woman out hunting, satirising women who enjoy this unfeminine pursuit. The woman is presented as ridiculous and almost maniacal in her intense concentration as she strides along purposefully. The image derives much of its humour from the juxtaposition of the woman's stereotypically feminine and masculine qualities. Thus, she is depicted wearing rouge, pearls, heeled shoes and an impractical hat, with a poodle by her side, yet, at the same time, she carries a double-barrelled shotgun and wears plus fours, a coat and a wide pouched belt containing ammunition. The contrast between her feminine appearance and masculine activity suggests the incongruity of a woman attempting to usurp a man's position in this intensely macho sport.

The Home's art criticism was equally eager to police the borders of acceptable femininity, focusing on the 'feminine' and 'decorative' aspects of female artists' work. A June 1922 interview with Thea Proctor concentrated exclusively on her opinions about fashion, architecture and interior decoration. ${ }^{45}$ The reduction of Proctor's artistic talent to the sartorial reflects the Home's condescending attitude towards female artists, whose work was repeatedly not accorded the same respect as that of male artists. The Home described Proctor's appearance at the 1927 Sydney Artists' Ball as 'exactly as if she had stepped from one of her own silken fans', a comment that served to reinforce this condescension towards women artists (see Figure 3). ${ }^{46}$

43 Vic Cowdroy, Cover Design, Home, March 1927. See Figure 2.

44 Joan Kerr, 'Victoria Ethel Cowdroy', in Heritage: The National Women's Art Book, ed. Joan Kerr (Roseville East, NSW: Art and Australia, distributed by Craftsman House, 1995), 334-35.

45 J. G. Lister, 'Australians Must Develop Taste Says Miss Thea Proctor', Home, June 1922, 37-38.

46 'Sydney S'Amuse', Home, October 1927, 28. See Figure 3. 
ANU Historical Journal II, Number 2

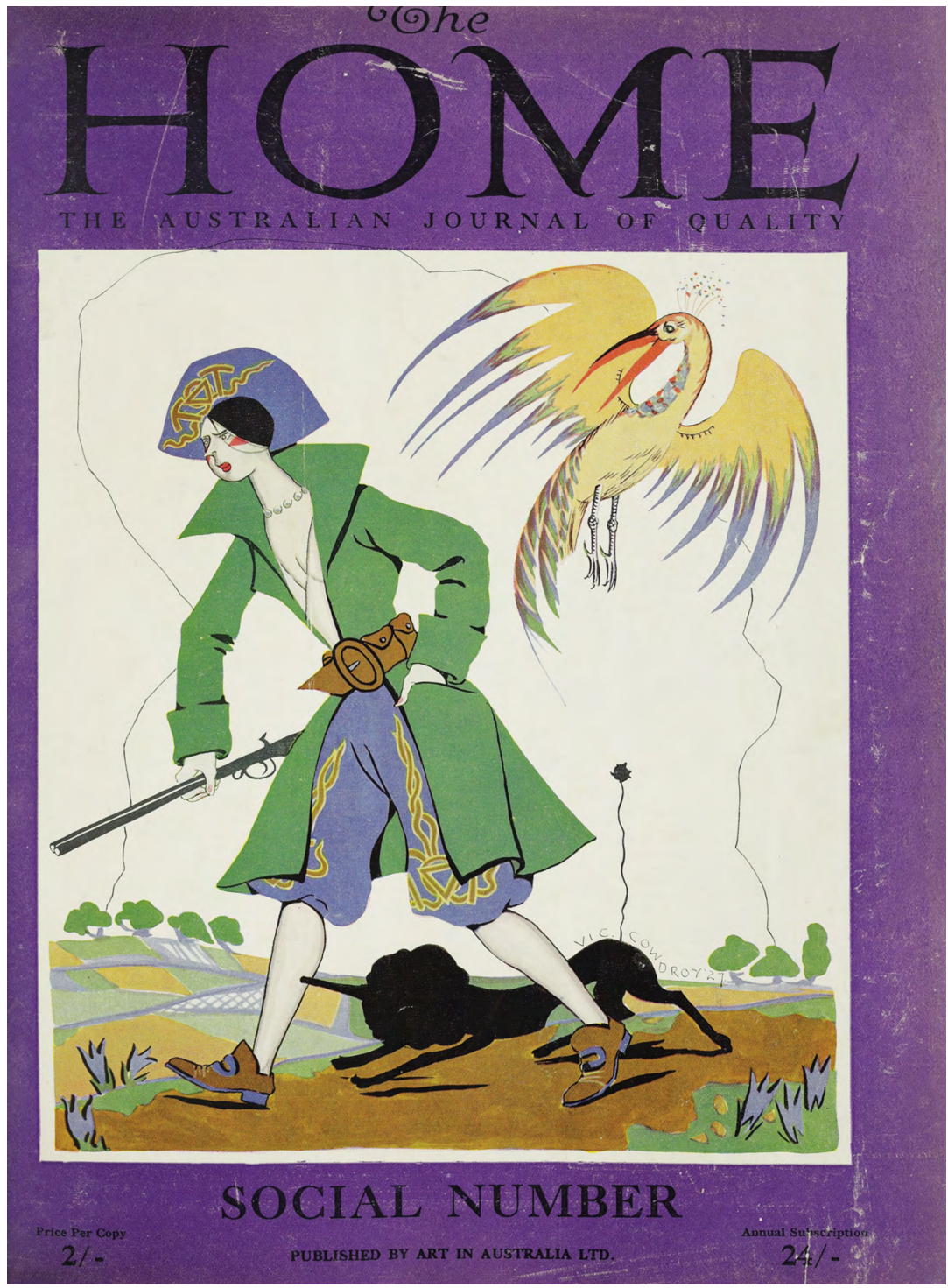

Figure 2: Vic Cowdroy, Cover Design, Home, March 1927. 


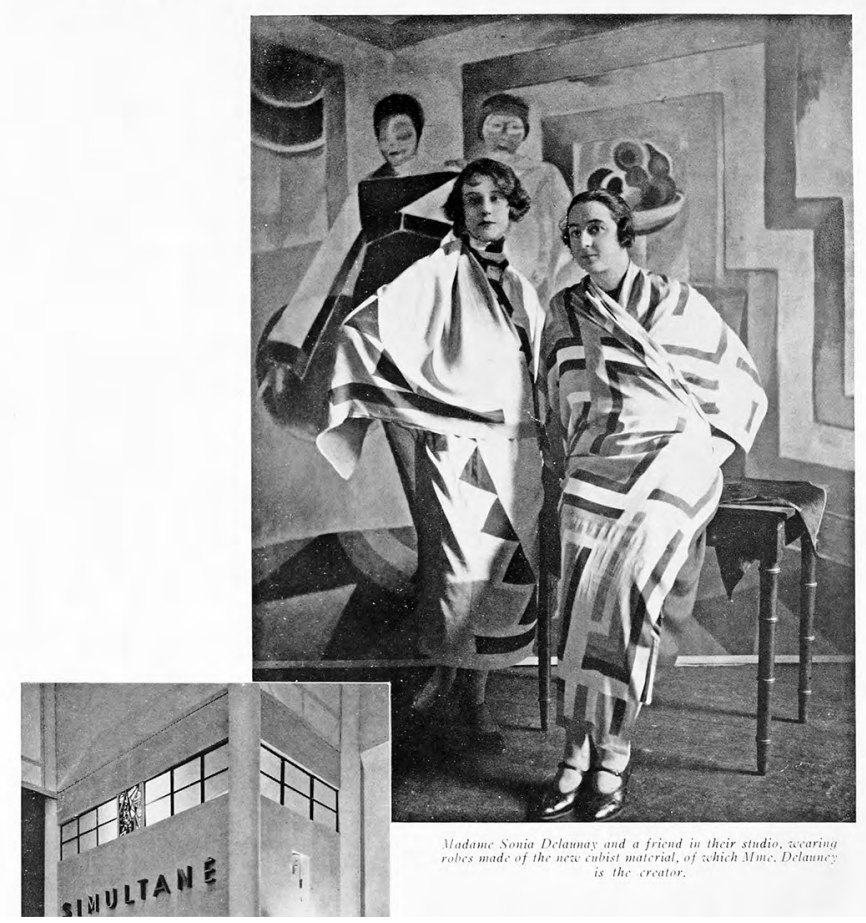

Figure 3: 'Cubist Materials at the Salon d'Automne', Home, February 1925, 24.

The Home's art critics were often conservative in their tastes, denigrating women's art as decorative and privileging the more stereotypically 'masculine' landscape genre. ${ }^{47}$ In 1926, the Home reproduced Elioth Gruner's 'Serpentine Hill' and extolled him as 'one of Australia's foremost landscape painters' ${ }^{48}$ By way of contrast, when the Home reported on Sonia Delauney's cubist fabrics shown at the 1925 Paris 'Exposition des Arts Décoratifs', the magazine paid more attention to the 'feminine' and decorative qualities of the fabric than to their innovative Orphic cubist design. ${ }^{49}$ While Helen Topliss has argued that this focus on Delauney's work is a positive example of the Home's promotion of artistic modernism,

47 Jeanette Hoorn, 'Women Make Modernism: Contesting Masculinist Art Criticism', in Strange Women: Essays in Art and Gender, ed. Jeanette Hoorn (Melbourne: Melbourne University Press, 1994), 21-25.

48 Elioth Gruner, 'Serpentine Hill', Home, July 1926, 12.

49 'Cubist Materials at the Salon d'Automne', Home, February 1925, 24. 
it is important to note the magazine's reductive focus on the ornamental over the more seriously artistic. ${ }^{50}$ Some scholars maintain that women's involvement in the less highly valued decorative arts enabled them to introduce to Australia a form of modernism that would have been rejected in the 'high arts' such as painting. ${ }^{51}$ Yet, the Home's privileging of the decorative over the artistic rather demonstrates the limitations of the magazine's promotion of modernism.

If the Home was often disapproving of modern art, it took an equally hostile approach towards modernist literature. Despite the efforts of critic and author Ethel Anderson, most other contributors to the magazine were either bemused about, or contemptuous of, modern literature and its female practitioners. Anderson embarked on a single-handed attempt to advocate for modern literature, and included approving references to modernist authors in her regular columns. ${ }^{52}$ She extolled modern, stream of consciousness, 'subjective prose', appropriated lines from Gertrude Stein and included quotations from the modernist poetry of T. S. Eliot in her articles. ${ }^{53}$ Yet, other contributors to the Home did not share Anderson's enthusiasm for the literary avant-garde. Instead, they remained bewildered by modern literature, and condemned what they did not fully understand.

Much of this ridicule was directed against female exemplars of modernism, as modern literature, like modern art, was denigrated for its perceived femininity. Far from quoting Stein appreciatively as Anderson had done, Jean Curlewis, a regular book reviewer for the Home, was baffled at the inclusion of a story by Stein in the 1926 edition of the annual short story anthology Georgian Stories. Curlewis was evidently perplexed at Stein's appearance in this typically conservative anthology, wondering whether the story was 'a joke' like those of 'cubist poets' who have 'put over' similar tricks on unsuspecting editors. ${ }^{54}$ Curlewis exclaimed irritably

50 Topliss, Modernism and Feminism, 106.

51 Jordan, 'Designing Women', 28-37; Pam James, “"No Thank You, but Do You Have Any Painted Fan Decorations?”: Modernist Women Artists and the Gatekeepers of Culture', in Wallflowers and Witches: Women and Culture in Australia 1910-1945, ed. Maryanne Dever (Brisbane: University of Queensland Press, 1994), 63-72.

52 Jane E. Hunt, 'The "Intrusion of Women Painters": Ethel Anderson, Modern Art and Gendered Modernities in Interwar Sydney, Australia', Women's History Review 21, no. 2 (2012): 171-88, doi.org/ 10.1080/09612025.2012.657885.

53 Ethel Anderson, 'Certain Things Considered', Home, September 1927, 81; Ethel Anderson, 'Certain Things Considered', Home, November 1927, 30; Ethel Anderson, 'The Archibald Prize', Home, March 1930, 26.

54 Jean Curlewis, 'A Bundle of Books', Home, January 1927, 44; Karen Leick, Gertrude Stein and the Making of an American Celebrity (New York and London: Routledge, 2009), 112-13. 
that 'I wish an editorial note had been attached to this story explaining it', and quoted in bewilderment various sentences from Stein's work as examples of her 'unintelligible' style. Writing about the literary magazine Triad, Carter describes a contemporary understanding of modernism 'as the mere outpourings of the subconscious without the "hard work" of literary craft'. ${ }^{55}$ The Home here registers a similar critique of the perceived superficiality of modernism, a critique that, in this case, is gendered.

If Curlewis was disconcerted by her contact with the literary avantgarde, Vivian Crockett's mock-imagist poem provided a more vicious condemnation of female literary modernism. Crockett's poem was dedicated 'with apologies to Amy Lowell', and its absurd lack of subject matter and ludicrously disjointed style derided the work of the American imagist poet. ${ }^{56}$ Although it could be argued that Crockett must have been relying on a certain familiarity with imagism for his joke to land, his poem failed to pay the close attention to a single image that was the distinctive feature of imagist poetry. Crockett portrayed the female modernist poet as frigid and unable to find romance, drawing attention to her 'single mattress', yet at the same time sexualising her by voyeuristically inviting the reader to imagine her 'lying' on the mattress 'wearing pyjamas'. ${ }^{57}$ This prurient male interest in a female poet's sleeping habits suggests a type of salacious humour more commonly associated with the Bulletin than with a putative women's magazine like the Home. Hence, such an objectification of the female poet feminises the modernist literary form in order to denigrate it.

The Home contained many more continuities with contemporary Australian masculine parochial publications than has been previously realised. Docker's bald pronouncement that 'the Home was pro-feminist' needs to be considerably qualified. ${ }^{58}$ While the Home was to some extent supportive of women's careers and lives outside the domestic sphere, it also contained a considerable body of masculinist literature, which either ignored women's concerns, or denigrated and ridiculed them. This male-

55 David Carter, 'Literary, but Not Too Literary; Joyous, but Not Jazzy: Triad Magazine, Antipodean Modernity and the Middlebrow', Modernism/Modernity 25, no. 2 (2018): 261, doi.org/10.1353/ $\bmod .2018 .0018$.

56 Vivian Crockett, 'With Apologies: To Amy Lowell, Imagist', Home, March 1923, 36.

57 The presentation of Lowell as frigid could be linked to the period's hostility to the spinster-or women perceived to be spinsters. See Sheila Jeffreys, The Spinster and Her Enemies: Feminism and Sexuality, 1880-1930 (London: Pandora Press, 1985).

58 Docker, 'Feminism, Modernism, and Orientalism in the Home', 120. 
orientated perspective is perhaps unsurprising since the Home's editors and directors were all male, and women were only ever employed as fashion editors or in the ancillary position of subeditor. ${ }^{59}$ Many of the journalists and authors writing for the Home also published in traditionally ultra-masculinist periodicals such as the Bulletin, Lone Hand, Vision and Aussie. ${ }^{60}$ While Robert Holden has maintained that the Home constructed an alternative, feminine national identity, the magazine in fact reproduced, far more often than it repudiated, contemporary masculine, parochial discourse. ${ }^{61}$ The Haggardian tale, 'Told in the Clubhouse', by G. C. Dixon, published in August 1925, is one example of the Home's indifference to women's experiences. ${ }^{62}$ In this imperial adventure story, two white men, engaged on a game hunt in Uganda, stumble upon another white man who challenges them to a murderous game of golf-the losers being eaten by a cannibal tribe of 'native' Africans. The story includes not a single female character, and the plot is largely incomprehensible to those without knowledge of the rules of golf. At a time when women faced considerable discrimination at golf clubs-being forced to play only when it would not inconvenience the male players, and being refused full club membership - the intended audience of this golfing story would surely have been men. ${ }^{63}$ Placing the game of golf in the masculine world of the colonial frontier completes the exclusion of women. In the story, golf and 'big game hunting' are in some sense interchangeable-the protagonist states that he 'decided to have a rest from golf and go big game shooting' ${ }^{64}$ The hyper-masculinity of this tale promotes a sense of male homosocial camaraderie that utterly excludes women. Here, the Home contributes to traditional notions of gendered behaviour, which failed to allow for the advances of modernity.

If Dixon's tale presented a fantasy of a world without women, then Montague Grover's 'Spoils to the Victor' activated contemporary anxieties about the dangers of modern women encroaching on traditionally maledominated domains. Grover's satirical drama ostensibly takes place in

59 Underhill, Making Australian Art, 194.

60 Examples of men who wrote for these publications as well as for the Home include, G. C. (Campbell) Dixon, Frank Middlemiss, Montague Grover, Vivian Crockett and Ernest O’Ferrall.

61 Holden, Cover Up, 97-99.

62 G. C. Dixon, 'Told In the Clubhouse', Home, August 1925, 22-23.

63 June Senyard, 'The Imagined Golf Course: Gender Representations and Australian Golf', The International Journal of the History of Sport 15, no. 2 (August 1998), 165, doi.org/10.1080/095 23369808714034; Brian Stoddart, 'Golf', in Sport in Australia: A Social History, ed. Wray Vamplew and Brian Stoddart (Cambridge: Cambridge University Press, 1994), 86.

64 Dixon, 'Told In the Clubhouse', 23. 
$1273 \mathrm{BC}$ in what is now Turkey, and dramatises a conflict between female warrior Amazons and male Lycian soldiers. ${ }^{65}$ Grover was a journalist, prolific playwright and author of short stories, who wrote extensively for the nationalistic magazines, the Bulletin and the Lone Hand ${ }^{66}$ His use of comic anachronism here allows him to satirise contemporary culture, and especially the perceived feminisation of the public sphere, and of professional life. Published in 1923, only five years after the end of World War I (WWI), Grover imagines women assuming military command, allowing him to comment on their increasing participation in the workforce. WWI had opened up new employment opportunities for women in banks, insurance offices, the railways and the public service ${ }^{67}$ But, after the war, there was a widespread backlash against such employment, as it was feared that women's success in these traditionally masculine jobs would deprive returned servicemen of work. ${ }^{68}$ Grover's denigration of female capabilities can be read as a response to fears of modern women's putative dominance over men in professional, and personal, life. Grover ridicules Iasis, the commander of the Amazons, as a comically self-important and disagreeable figure, who is described as a 'nasty cat', and as 'straining very hard to maintain her dignity' when she faces the 'amused tolerance' of her male counterparts. ${ }^{69}$ By contrast with Iasis, who is barely able to control her flighty female subordinates, the male characters display valorous and martial abilities. The commander of the Lycian Army, Bellerophontes, heroically defeats the Chimæra, a mythical, winged creature with fire-breathing heads. Bellerophontes is mounted on the winged horse Pegasus, a metaphorical fighter plane, and wages a daring air battle against his foe, which Grover describes in a breathlessly admiring narration. While Bellerophontes is allowed his moment of genuine heroic victory, the female characters' physical prowess is constantly undermined. Iasis manages to disarm her opponent, but she succumbs to his flattery and proposals of a relationship, demonstrating that, for Grover, women will choose love over work. Grover's attitude towards women is made clear in the final scene, in which each of the Amazons is shown not to be fighting their male opponents, but rather

65 Montague Grover, 'Spoils to the Victor', Home, March 1923, 57-72.

66 Sally O'Neill, 'Grover, Montague MacGregor (Monty) (1870-1943)', Australian Dictionary of Biography, National Centre of Biography, Australian National University, accessed 1 July 2020, adb.anu.edu.au/biography/grover-montague-macgregor-monty-6500/text11147.

67 Fox and Lake, Australians at Work, 144.

68 Cameron, 'The Flappers and the Feminists', 265.

69 Grover, 'Spoils to the Victor', 62. 
'in a close embrace' with a Lycian soldier. ${ }^{70}$ Hence, Grover's drama manifests a reactionary attitude towards modern women's employment, as he argues that women will ultimately return to their 'natural' position of subordination to men.

Indeed, while the Home supported a few women's careers, it remained largely ambivalent about the modern women who worked outside the domestic sphere. The magazine ignored feminist debates about women's right to work, equal pay and economic independence. ${ }^{71}$ Feminists active during the period, such as Rose Scott and Jessie Street, advocated for women to be protected from violent, abusive and controlling men. They worked for the independence of married women, and argued for the age of consent to be raised and for the rights of mothers. ${ }^{72}$ Recognising that working-class women struggled to secure paid employment and to care for their children, feminists in the labour movement campaigned for a state-sponsored income for mothers, to save them from reliance on potentially abusive men. ${ }^{73}$ Such political feminism was far from the concerns of readers of the Home.

While feminists of the period fought for women's right to work and to control their own income, the Home's well-to-do female audience did not so much require a career as a 'remunerative hobby', as one article described it. ${ }^{74}$ When the Home's genteel upper-middle-class readership found work, they largely did so not out of necessity but through a 'spirit of self-reliance'. Topliss claims that the Home 'celebrated the achievements of women in all fields' and, as I have noted above, Docker has described the magazine as explicitly 'pro-feminist'. Yet, I argue that it is a mistake to view the publication as in any way aligning itself with feminist movements of the period..$^{75}$ Instead, the magazine largely focused its attention on society women, and only championed a small number of women engaged in socially sanctioned literary or artistic careers. For example, an August 1925 selection of portraits of 'notable women' now 'resident abroad'

70 Grover, 'Spoils to the Victor', 72.

71 Edna Ryan and Anne Conlon, Gentle Invaders: Australian Women at Work (Ringwood, Melbourne: Penguin, 1989), 121; Marilyn Lake, Getting Equal: The History of Australian Feminism (Sydney: Allen \& Unwin, 1999), 97-109.

72 Lake, Getting Equal, 56-57.

73 Lake, Getting Equal, 74-75.

74 'The Career and the Remunerative Hobby for the Australian Girl', Home, June 1924, 78.

75 Topliss, Modernism and Feminism, 50; Docker, 'Feminism, Modernism, and Orientalism in the Home', 120. 
included the painter Bess Norris and actress Marie Ney, but also Mrs Dudley Coats, described simply as 'the wife of Captain Dudley Coats', and 'H.H. the Rani of Pudukota, the beautiful wife of H.H. the Rajah of Pudukota, who was well known as Miss Mollie Fink, of Melbourne'. ${ }^{76}$

In contrast with these lavish 'society' photographs in pride of place near the front of the magazine, an article about the 'motor mechanic and chauffeuse' Alice Anderson was relegated to the rear of the publication (see Figure 4). ${ }^{77}$ The profile of Anderson highlighted her transgression of feminine propriety. The article drew attention to Anderson's 'boyishlooking figure', her 'dungarees', her 'cropped hair' and the 'khaki coats and breeches' that her employees wore. ${ }^{78}$ Yet the article condescendingly referred to Anderson as a 'very feminine person' and described her garage assistants as 'girls', not women, adding that they made 'attractive and reliable chauffeuses'. ${ }^{79}$ This insistence on the feminine form of 'chauffeur', and on the maintenance of appropriate standards of feminine beauty, shows that women adopting male fashions and working in a traditionally masculine profession activated fears about 'modern' women rejecting conventional womanhood. While Lucy Chesser has found that women's cross-dressing in the 1920s was not associated with potential homosexuality, rumours were rife about lesbianism at Anderson's garage. ${ }^{80}$ While it is impossible to substantiate such claims, the persistence of reports of this kind speaks to contemporary anxieties about the suspect 'feminine masculinity' of these women mechanics. ${ }^{81}$ By questioning the propriety of Anderson's masculine dress, the Home demonstrated its lack of tolerance for deviation from traditionally gendered norms of behaviour, and hence its limited espousal of the changing social world of modernity.

76 'London Portraits', Home, December 1920, 24.

77 'The Woman Who Does', Home, December 1920, 74.

78 'The Woman Who Does', 74; 'Miss Alice Anderson', Home, December 1920, 74, photograph. See Figure 4.

79 Loretta Smith, A Spanner in the Works: The Extraordinary Story of Alice Anderson and Australia's First All-Girl Garage (Sydney: Hachette Australia, 2019), 186-87.

80 Lucy Chesser, Parting with My Sex: Cross-Dressing, Inversion and Sexuality in Australian Cultural Life (Sydney: Sydney University Press, 2008), 309-11.

81 Clarsen, Eat My Dust, 116-17. 


\section{The Woman Who Does}

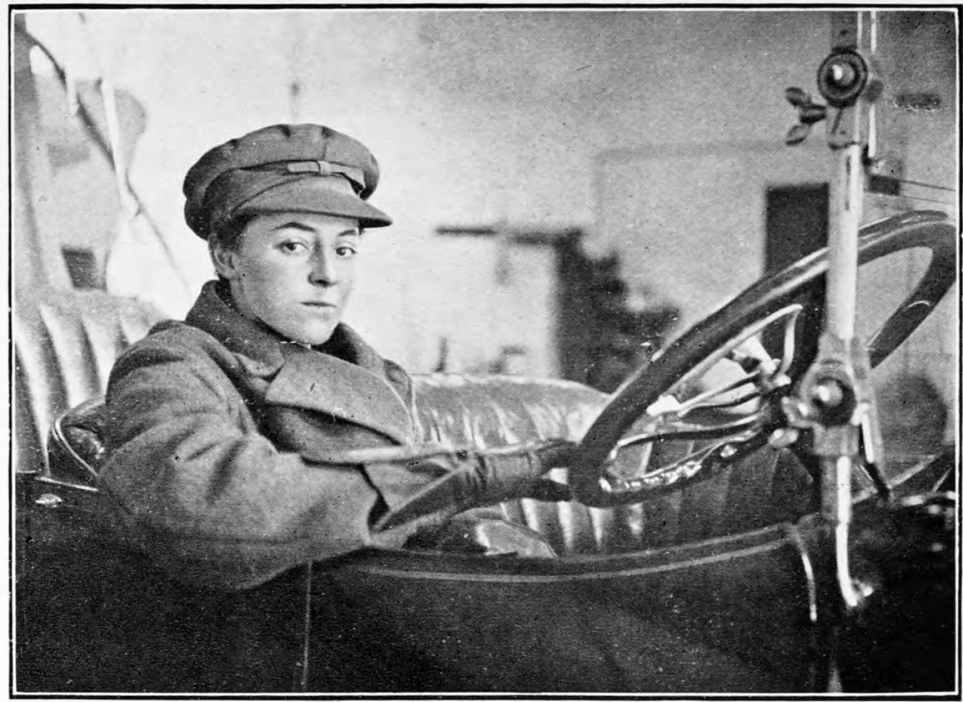

MISS ALICE ANDERSON

Motor Mechanic and Chauffeuse, Melbourne.

Figure 4: 'Miss Alice Anderson', Home, December 1920, 74.

The Home magazine both reflected and challenged Australian modernity of the 1920s. While critics have argued that the Home was a major promoter of modernism, the magazine was in fact ambivalent about, and sometimes antagonistic towards, artistic and literary modernism. The Home was especially wary of women's involvement in these avant-garde movements, and often sought to ridicule or denigrate women's creative achievements. Moreover, the Home displayed considerable anxiety about modern women taking on roles outside the domestic sphere, and especially about women holding traditionally male-dominated jobs. While the Home championed the careers of a small number of women artists and writers, it did not feel the need to advocate for women's economic independence. Instead, it worried about working women transgressing the boundaries of feminine decorum. These reactionary elements of the Home demonstrate that, for all its putative desire to 'touch [on] whatever seems most modern', the Home's response to modernity was limited, conservative and often hostile. ${ }^{82}$

82 Sydney Ure Smith, 'The Home: How It Proposes To Be Of Service To You', Home, February 1920,3 . 
This text is taken from ANU Historical Journal II: Number 2, published 2020 by ANU Press, The Australian National University, Canberra, Australia.

doi.org/10.22459/ANUHJII.2020.03 